\title{
Inhibition of Enzymatic Browning of Crown Daisy by Maillard Reaction Products
}

\author{
Ji-Hae Kim, Hyeon-Seung Song and Inshik Park*
}

Department of Food Science and Nutrition, Dong-A University, Busan 604-714, Korea

Received October 16, 2012 /Revised November 8, 2012 /Accepted November 8, 2012

\begin{abstract}
The study was conducted to investigate the effect of Maillard reaction products (MRPs) on enzymatic browning of crown daisy (Chrysanthmum coronarium var. spatiosum). The MRPs prepared by heating various amino acid and sugar at $90^{\circ} \mathrm{C}$ caused a strong inhibitory effect on crown daisy polyphenol oxidase (PPO, $\sigma$-diphenol oxygen oxidoreductase, EC 1.10.3.1). As the reaction time of the solution containing glycine and glucose increased at $90^{\circ} \mathrm{C}$, the production of MRPs was increased, whereas the amounts of glycine and glucose were decreased. Accordingly, the inhibitory effect of crown daisy PPO activity by MRPs was increased as the amounts of synthesized MRPs were increased. The MRPs synthesized from the various amino acids and sugars significantly reduced the PPO activity, particularly MRPs prepared by glutamine and xylose. The Michealis-Menten constant value $\left(\mathrm{K}_{\mathrm{m}}\right)$ of crown daisy PPO with catechol as a substrate was $22.0 \mathrm{mM}$, and MRPs were a noncompetitive inhibitor against crown daisy PPO.
\end{abstract}

Key words : Crown daisy, polyphenol oxidase, Maillard reaction products, enzyme inhibitor

\section{Introduction}

Enzymatic Browning occurs usually in fruits and vegetables during post-harvest handling, processing and storage [9]. Enzymatic browning is a major factor contributing to quality loss depending on the foods and beverages [15]. The browning phenomenon usually impairs the sensory properties of products because of the associated changes in color, flavor and softening [16]. Browning in fruits and vegetables is caused by the enzymatic oxidation of phenolic compounds by polyphenol oxidase [6]. Polyphenol oxidase (PPO, odiphenol : $\mathrm{O}_{2}$ oxidoreductase, EC 1.10.3.1) is a copper-containing enzyme, which is also known as catechol oxidase, catecholase, diphenol oxidase, odiphenolase, phenolase and tyrosinase [19]. PPO catalyzes either one or two reactions involving molecular oxygen. The first type of reaction is hydroxylation of monophenols leading to formation of odihydroxy compounds. The second type of reaction is oxidation of o-dihydroxy compounds to quinones [3].

Prevention of browning of fruits and vegetables by PPO is important issue in food industry. Enzymatic browning by PPO can be prevented by inactivation of PPO by heating or the addition of inhibitors such as sulfite-containing compounds, ascorbic acid and its analogs as well as cysteine $[5,10,12,13,20,22]$. Fruits or vegetables can be protected from browning by heating, but it can deteriorate the nutritional and sensory properties of the fruits and vegetables.. Although sulfite-containing compounds are effective to prevent browning, it could be harmful for human health. Accordingly, there is an increasing demand of consumers for substituting synthetic compounds with natural substances as food ingredients [9].

The Maillard reactions are common, non-enzymatic browning reactions taking place between sugars and amino acid during the thermal processing of food materials, and produced a dark brown to black complex polymer known as melanoidin [4]. Color formation is the primary characteristics of melanoidin formation, but melanoidin contribute to the sensory properties, modulating texture and flavor of foods [17]. In addition, growing evidence suggests that melanoidins have health beneficial properties, such as chemopreventive, antioxidant and antimicrobial activities, and the ability to chelate different minerals. In the gastrointestinal tract, melanoidins behave not only as antioxidants, but also as dietary fiber by promoting the growth of bifidobacteria [17]. The property of crown daisy PPO is yet to be determined, and no previous research has been performed on inhibition of crown daisy PPO. In this work, we attempt to evaluate Maillard reaction products (MRPs) as natural inhibitor of crown daisy browning by PPO.

\footnotetext{
*Corresponding author

Tel : +82-51-200-7322, Fax : +82-51-200-7535

E-mail : ispark@dau.ac.kr
} 


\section{Materials and Methods}

\section{Materials}

Crown daisy (Chrysanthemum coronarium var. spatiosum) was purchased from a local market in Busan, Korea. All amino acids, sugars, catechol, glucose oxidase and peroxidase were obtained from Sigma Chemical Co.

\section{Assay of crown daisy PPO}

Crown daisy $(100 \mathrm{~g})$ was homogenized with $100 \mathrm{ml}$ of a $50 \mathrm{mM}$ phosphate buffer at $\mathrm{pH} 6.6$ for $3 \mathrm{~min}$. The homogenate was centrifuged at $15,000 \times g$ for $20 \mathrm{~min}$, and the supernatant was collected. All steps were carried out at $4{ }^{\circ} \mathrm{C}$. The PPO activity was assayed with $0.2 \mathrm{M}$ catechol as a substrate by a spectrophotometric procedure (Ultrospec 3000, Pharmacia Biotech) [26]. The assay mixture contained $0.1 \mathrm{ml}$ of crown daisy PPO, $0.9 \mathrm{ml}$ of a $50 \mathrm{mM}$ phosphate buffer at $\mathrm{pH}$ 6.6, and $1.0 \mathrm{ml}$ of MRP was incubated for $5 \mathrm{~min}$ at $25^{\circ} \mathrm{C}$. After this incubation, $1.0 \mathrm{ml}$ of $0.2 \mathrm{M}$ catechol was added to the assay mixture, and the increase in absorbance at $420 \mathrm{~nm}$ at $25^{\circ} \mathrm{C}$ was recorded automatically for $1 \mathrm{~min}$. The total assay volume was $3.0 \mathrm{ml}$.

\section{Synthesis of MRPs}

MRPs of different amino acids and sugars were obtained by heating $5.0 \mathrm{ml}$ of concentration of various amino acid and sugar solutions at $90^{\circ} \mathrm{C}$ for various time intervals. The MRP formation was evaluated by measuring absorbance at $420 \mathrm{~nm}$.

\section{Glucose and glycine determination}

Glucose was quantitatively determined by enzymatic assay method using glucose oxidase/peroxidase [14]. The assay mixture contained $2.6 \mathrm{ml}$ of a $0.1 \mathrm{M}$ acetate buffer at $\mathrm{pH} 5.5,0.1 \mathrm{ml}$ of MRPs synthesized from glucose/glycine mixture and $0.1 \mathrm{ml}$ of $0.45 \mathrm{M}$ guaiacol. The assay was initiated by adding $0.2 \mathrm{ml}$ of glucose oxidase/peroxidase. The total assay volume was $3.0 \mathrm{ml}$. The increase in absorbance at $460 \mathrm{~nm}$ was recorded automatically for $2 \mathrm{~min}$. The glycine was determined by ninhydrin method [23].

\section{Statistical Analysis}

All analysis were performed in triplicate and the data reported as mean \pm standard deviation (SD).

\section{Results and Discussion}

Fig. 1 demonstrates time dependent formation of MRPs,

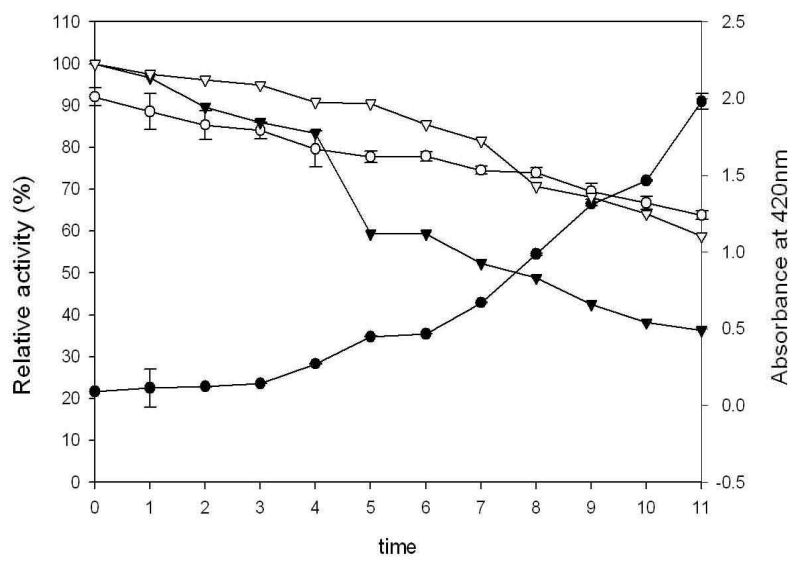

Fig. 1. Effect of reaction time of glucose and glycine on formation of Maillard reaction product, polyphenol oxidase activity, amount of glucose and glycine. Maillard reaction product formation was expressed as absorbance at $420 \mathrm{~nm}(\mathbf{\bullet}-\mathbf{\bullet})$, while polyphenol oxidase activity $(\mathrm{O}$ $\bigcirc)$, glucose $(\boldsymbol{\nabla}-\boldsymbol{\nabla})$ and glycine amount $(\nabla-\nabla)$ were expressed as relative activity (\%).

amount of glucose and glycine, and the inhibition of crown daisy PPO by formed MRPs. The MRPs were prepared by reacting $1.0 \mathrm{M}$ glucose and $1.0 \mathrm{M}$ glycine at $90^{\circ} \mathrm{C}$ for various time intervals (hrs). Color formation is the primary characteristics of Maillard reaction, and the color produced by Maillard reaction can be readily measured by reading the absorbance at $420 \mathrm{~nm}$. As the reaction time of glycine and glucose increased, MRPs formed by heating glucose/glycine mixture also increased. The inhibitory effect of produced MRPs also increased against crown daisy PPO as the production of MRPs was increased, whereas the amounts of glycine and glucose were decreased. Fig. 2 shows the effect of

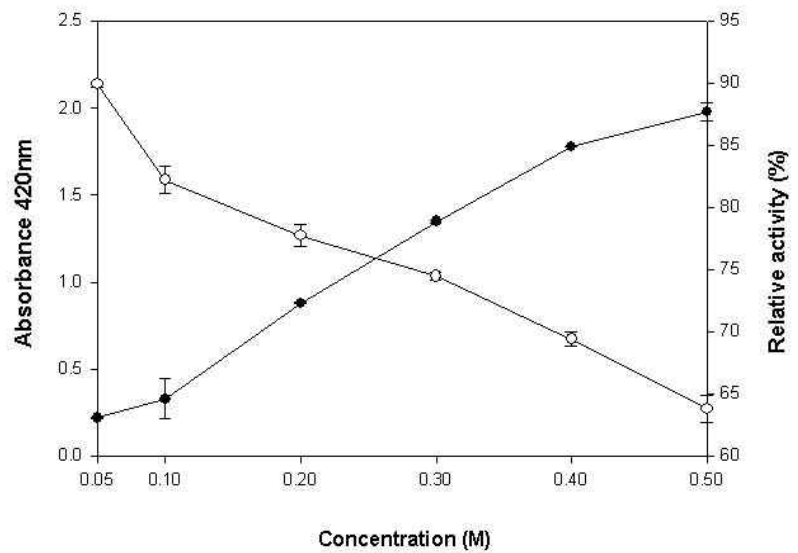

Fig. 2. Effect of glucose and glycine concentration on inhibitory effect of crown daisy polyphenol oxidase activity. Absorbance at $420 \mathrm{~nm}(\mathbf{-}-\mathbf{\bullet})$; Relative activity of polyphenol oxidase $(\mathrm{O}-\mathrm{O})$ 
glucose/glycine amount for production of MRPs on inhibitory effect of crown daisy PPO. As the amount of glucose/glycine increases, the production of MRPs and inhibitory effect of crown daisy PPO by the produced MRPs were also increased. This shows clearly that the inhibitory effect of crown daisy PPO was due to the presence of MRPs. Ames reported that color formation is likely due both to the formation of low molecular weight compounds and to the presence of melanoidins with high molecular weight [1]. Gomyo explained that the browning intensity of melanoidins has been found to be directly related to its degree of polymerization [7].

It is not clear which compound in MRPs is responsible for the inhibitory activity against crown daisy PPO. However, enzymatic browning is the oxidation process of polyphenol by PPO, and reducing agents can inhibit the oxidation by PPO. It was reported that various reducing agents can be used as inhibitors of PPO [5,10,12,13,20,22]. Therefore, it can be assumed that reducing activities formed during Maillard reaction might be responsible for the inhibition of crown daisy PPO. It was also reported that Maillard reaction products inhibited potato and apple PPO [14,24]. Reductone moiety present in the Maillard reaction products has been reported to exhibit both reducing and chelating properties [18] in addition to oxygen scavenging properties [8]. Therefore, the reductone moiety in the melanoidine's structure may prevent browning by reducing the copper of PPO. Another possibility is that the reductone in the Maillard reaction product may be capable of converting the quinone back to diphenol, thus preventing the polymerization of quinone [8]. The Maillard reaction is exceptionally widespread. It occurs virtually ubiquitously in foodstuffs, during processing at elevated temperatures or during storage for prolonged periods. It also increases reducing power during Maillard reaction process. Increased antioxidant activity or more negative redox potential is also one of symptoms of Maillard reaction. This has considerable significance, because as far as food is concerned, one of the main ways in which they deteriorate chemically is through oxidation [21].

The inhibitory effect of MRPs synthesized from different sugars with constant amount of glycine $(1.0 \mathrm{M})$ on crown daisy PPO activity is shown in Table 1 . The enzyme was most inhibited by MRPs prepared with xylose followed by fructose, glucose, lactose, maltose and sucrose. This result coincides well with the previous report that pentoses generally produced more browning and greater antioxidant
Table 1. Effect of Maillard reaction products produced by various sugars with $1 \mathrm{M}$ glycine on crown daisy polyphenol oxidase activity

\begin{tabular}{lc}
\hline Sugars Compounds & Relative activity $(\%)$ \\
\hline control & 100.0 \\
sucrose & $75.2 \pm 2.25$ \\
maltose & $71.5 \pm 3.31$ \\
lactose & $69.3 \pm 3.02$ \\
glucose & $63.8 \pm 1.09$ \\
fructose & $58.5 \pm 1.43$ \\
xylose & $10.6 \pm 0.84$ \\
\hline
\end{tabular}

All analysis were performed in triplicate and the data reported as mean \pm standard deviation (SD).

Table 2. Effect of Maillard reaction products produced by various amino acids with $1.0 \mathrm{M}$ glucose on crown daisy polyphenol oxidase activity

\begin{tabular}{lc}
\hline Amino acids Compounds & Relative activity $(\%)$ \\
\hline control & 100.0 \\
asparagine & $80.1 \pm 0.97$ \\
valine & $75.0 \pm 0.35$ \\
glycine & $63.8 \pm 1.07$ \\
tryptophan & $57.7 \pm 1.5$ \\
glutamine & $37.3 \pm 2.2$ \\
\hline
\end{tabular}

All analysis were performed in triplicate and the data reported as mean \pm standard deviation (SD).

activity than hexose [25]. MRPs prepared from pentose are the most potent inhibitor against crown daisy PPO followed by hexose and disaccharides. Since sucrose is not reducing sugar, it may be least effective sugar to produce MRPs against crown daisy PPO.

The inhibitory effect of MRPs synthesized from different amino acids with constant amount of glucose $(1.0 \mathrm{M})$ on crown daisy PPO activity is exhibited in Table 2. Among tested amino acid, glutamine was the most efficient followed by tryptophan, glycine, valine, and asparagine.. However, it is not possible to establish an overall ranking of amino acids according to antioxidative activity of the derived melanoidins, because combination with different carbonyl compounds leads to different effects $[2,11]$.

The Michaelis-Menten constant $\left(K_{\mathrm{m}}\right)$ of crown daisy PPO was measured at $\mathrm{pH} 6.8$ and $25^{\circ} \mathrm{C}$. From double reciprocal plot, the $K_{m}$ values of crown daisy PPO in the absence and presence of MRPs were measured. Fig. 3 shows a plot of $1 / v$ against $1 /[S]$ in the absence and presence of MRPs. Both reciprocal plots that intersect on the horizontal axis at a value of $-1 / K_{m}$ are obtained. From the plots, $K_{m}$ value of crown daisy PPO with catechol as a substrate was 


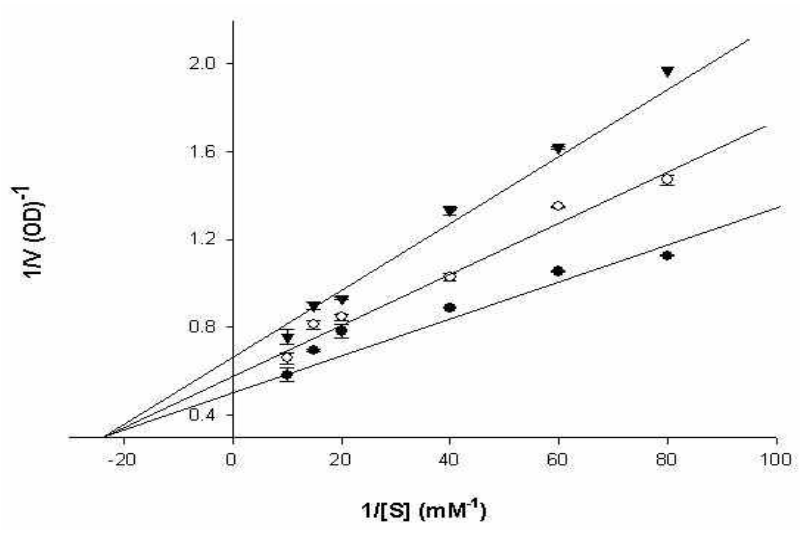

Fig. 3. Lineweaver-Burk plots of polyphenol oxidase from crown daisy with Maillard reaction products. Catechol was used as a substrate. Control (--); Maillard reaction products (absorbance at $420 \mathrm{~nm}=0.099)(\bigcirc-\bigcirc)$; Maillard reaction products (absorbance at 420 $\mathrm{nm}=0.198)$

determined as $22.0 \mathrm{mM}$. Since the $\mathrm{K}_{\mathrm{m}}$ value of crown daisy PPO in the presence of MRPs was not changed as shown in Fig. 3, the MRPs seems to be non-competitive inhibitor against crown daisy PPO.

\section{Acknowledgment}

This work was supported by the Dong-A University the research fund.

\section{References}

1. Ames, J. M. 1992. The Maillard reaction. pp. 99-153, In Hudson, B. (ed.), Biochemistry of Food Proteins. Elsevier Applied Science, London.

2. Bedinghaus, A. J. and Ockerman, H. W. 1995. Antioxidative Maillard reaction products from reducing sugars and free amino acids in cooked ground pork patties. J. Food Sci. 60, 992-995.

3. Busch, J. M. 1999. Enzymatic browning in potatoes: a simple assay for polyphenol oxidase catalyzed reaction. Biochem Educ. 27, 171-173.

4. Chandra, R., Bharagava, R. N. and Rai, V. 2008. Melanoidins as major colorant in sugarcane molasses based distillery effluent and its degradation. Bioresour. Technol. 99, 4648-4660.

5. Ding, C., Chachin, K., Ueda, Y. and Wang, C. Y. 2002. Inhibition of loquat enzymatic browning by sulfhydryl compounds. Food Chem 76, 213-218.

6. Friedman, M. 1996. Food Browning and Prevention: An Overview. The American Chemical Society, 44, 632-653.

7. Gomyo, T., Kato, H., Udaka, K., Horikoshi, M. and Fujimaki, M. 1972. Chemical studies on melanoidins: Part III. Effects of heating on chemical properties of melanoidin prepared from glycine-xylose system. Agric. Biol. Chem 36, 125-132.

8. Hayase, F., Hirashima, S., and Okamota, G. 1989. Kato H. Scavenging of active oxygen by mellanodines. Agric. Biol. Chem 53, 3383-3385.

9. Jang, M. S., Sanada, A., Ushio, H., Tanaka, M. and Ohshima, T. 2002. Inhibitory effects of 'Enokitake' mushroom extracts on polyphenol oxidase and prevention of apple browning. Lebens-Wissen. Technol. 35, 697-702.

10. Jiang, Y. and Fu, J. 1998. Inhibition of polyphenol oxidase and the browning control of litchi fruit by glutathione and citric acid. Food Chem 62, 49-52.

11. Kawashima, K., Itoh, H. and Chibata, I. 1977. Antioxidant activity of browning products prepared from low molecular carbonyl compounds and amino acids. J. Agric. Food Chem 25, 202-204.

12. Langdon, T. T. 1987. Preventing browning in freshly prepared potatoes without the use of sulfiting agents. Food Technol. 41, 64-67.

13. Lee, M., Kim, Y., Kim, N., Kim, G., Kim, S., Bang, K. and Park, I. 2002. Prevention of browning in potato with a heat-treated onion extract. Biosci. Biotechnol. Biochem 66, 856-858.

14. Lee, M. and Park, I. 2005. Inhibition of potato polyphenol oxidase by Maillard reaction products. Food Chem 91, 57-61.

15. Martinez, M. V. and Whitaker, J. R. 1995. The biochemistry and control of enzymatic browning. Trends Food Sci. Technol. 6, 195-200.

16. McEvily, A. J., lyengar, R. and Otwell, W. S. 1992. Inhibition of enzymatic browning in foods and beverages. Crit. Rev. Food Sci. Nutri. 32, 253-273.

17. Morales, F. J., Somoza, V. and Fogliano, V. 2012. Physiological relevance of dietary melanoidins. Amino Acid 42, 1097-1109.

18. Namiki, M. 1998. Chemistry of Maillard reactions: recent studies on the browning reaction mechanism and the development of antioxidants and mutagens. Adv. Food Res. 38, 115-183.

19. Negishi, O., Negishi, Y. and Ozawa, T. 2002. Effects of food materials on removal of Allium-specific volatile sulfur compounds. J. Agric. Food Chem 50, 3856-3861.

20. Negishi, O. and Ozawa, T. 2000. Inhibition of enzymatic browning and protection of sulfhydryl enzymes by thiol compounds. Phytochemistry 54, 481-487.

21. Nurten, H. 2005. The Maillard Reaction: Chemistry, Biochemistry and Implication, Royal Society of Chemistry, Cambridge, UK.

22. Pizzocaro, F., Torreggiani, D. and Gilardi, G. 1993. Inhibition of apple polyphenol oxidase by ascorbic acid, citric acid and sodium chloride. J. Food Proc. Preser. 17, 21-30.

23. Plummer, D. T. 1985. An Introduction to Practical Biochemistry. McGraw Hill. London.

24. Tan, B. K. and Harris, N. D. 1995. Maillard reaction products inhibit apple polyphenol oxidase. Food Chem 53, 267-273.

25. Wijewickkreme, A. N. and Kitts, D. D. 1977. Influence of 
reaction conditions on the oxidative behavior of model Maillard reaction products. J. Agric. Food Chem 45, 45714576.
26. Zauberman, G., Ronen, R., Akerman, M. and Weksler, A., Rot, I. and Fuch, Y. 1991. Postharvest retention of the red color of litchi fruit pericarp. Scientia. Hort. 47, 89-97.

\section{초록 : 마이얄반응생성물(Maillard reaction product)에 의한 쑥갓의 효소적갈면 억제}

김지혜 · 송현승 · 박인식*

(동아대학교 식품영양학과)

다양한 아미노산과 당을 $90^{\circ} \mathrm{C}$ 에서 반응시켜 생성한 마이얄반응 생성물(Maillard reaction product)은 쑷갓에서 추출한 폴리페놀산화효소(polyphenol Oxidase, $\mathrm{PPO}$ )를 강하게 저해하였다. 글리신(glycine)과 포도당을 함유한 반응물으로부터 $\mathrm{MRP}$ 의 생성은 $90^{\circ} \mathrm{C}$ 에서 반응시간에 따라 직선적으로 증가하였으나 글리신과 포도당의 양은 상 대적으로 감소하였다. 반응액에서 $\mathrm{MRP}$ 의 증가함에 따라 반응액은 쑥갓 $\mathrm{PPO}$ 활성을 비례적으로 강하게 저해하였 다. 실험에 사용한 아미노산과 당중에서 글루타민과 자일로스를 아미노산과 당으로 이용했을 경우에 생성된 $\mathrm{MRP}$ 가 쑥갓 $\mathrm{PPO}$ 의 활성에 강한 저해제로 작용하였다. 카테콜을 기질로 사용한 쑥갓 $\mathrm{PPO}$ 의 마이클레스 상수 (Michaelis Menten constant)는 $22.0 \mathrm{mM}$ 이었으며, $\mathrm{MRP}$ 는 쑥갓 $\mathrm{PPO}$ 의 비경쟁적 저해제로 작용하였다. 